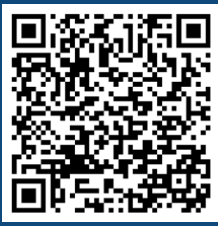

Keywords:

Remote sensing

Synthetic aperture radar

Forest biomass

Received 23/07/2019

Accepted 07/1 I/2019

Correspondence: janisson.eng@gmail.com
Janisson Batista de Jesus ${ }^{1 a+}$, Tatiana Mora Kuplich $2 \mathrm{a}$

\section{APPLICATIONS OF SAR DATA TO ESTIMATE FOREST BIOPHYSICAL VARIABLES IN BRAZIL}

JESUS, J. B.; KUPLICH, T. M. Applications of sar data to estimate forest biophysical variables in Brazil. CERNE, v. 26, n. I, p.88-97, 2020.

\section{HIGHLIGHTS}

Increasing number of articles presenting the use SAR remote sensing for forestry studies in Brazil.

Most of articles presenting the use SAR remote sensing for forestry studies have Brazilian Amazonia as study site or Eucaliptus plantations elsewhere.

$\mathrm{L}$ and $\mathrm{P}$ bands data are the most indicated for biomass estimates, although still subject to the backscatter saturation effect.

Polarimetric and interferometric studies are becoming a reality with adequate free SAR data and processing systems available.

\section{ABSTRACT}

The use of SAR images has been highlighted in scientific research focused on forest data collection worldwide. Thus, the present work aimed at gathering studies turned to the application of SAR images to obtain biophysical variables of forests in Brazil. Based on studies published in recognized databases, a growing amount of publications over time was observed with more focus on researches made mainly in Amazonian biome, followed by planted forests with eucalyptus destined to wood production. Most works were made based on airborne radar data, followed by ALOS/PALSAR and JERS-I orbital data. It is remarkable the scientific knowledge produced using radar data from Brazilian forests, demonstrating that this technology is an other tool for studies and applications in Forestry Sciences that can assist in the country's forestry management. Nevertheless, the need of studies on the several forest typologies across Brazil was evidenced, along with the lack of research related to radar use to estimate biophysical variables in caatinga and Atlantic Forest biomes. 


\section{INTRODUCTION}

Remote systems based on transmission and reception of echoes (backscattering) using electromagnetic radiation in the microwave regions are active sensors called radars, which can present real aperture (RAR) or synthetic aperture (SAR). This latter is widely used, and its response is determined by the sensor parameters (angle of incidence, polarization and incident wave frequency) and the object characteristics (dielectric constant, roughness and geometry) (KUPLICH, 2003).

The interaction of microwave radiation with vegetation is highly related to the wavelength used, which is inversely proportional to the system operation frequency, varying basically from band $X(\sim 3 \mathrm{~cm})$, C $(\sim 6 \mathrm{~cm}), S(\sim 15 \mathrm{~cm}), \mathrm{L}(\sim 24 \mathrm{~cm})$ to band $\mathrm{P}(\sim$ $69 \mathrm{~cm})$, and, the longer the microwave length, the greater it penetrates the vegetation canopy (Figure la) (KAASALAINEN et al., 20I5).

The SAR system parameters and object characteristics influence backscattering mechanisms, which can be: single bounce (specular reflection), double bounce (adjacent smooth surfaces) or volumetric (non homogeneous forest canopy and stems) (JOSHI et al., 20I5). Therefore, the backscattered signal can have different sources as it reaches each part of vegetation structure and the soil (Figure Ib), which is decisive for studies with forestry.
Each type of vegetation has a specific structure that will interact differently with SAR microwaves, when identifying different succession stages of the Amazon Forest (SANTOS and GONÇALVES, 2009). The polarization of the SAR signal, which refers to the orientation of the electric field emitted and received by the SAR sensor in the vertical $(V)$ or horizontal $(H)$ axis, and can be co-polarized $(\mathrm{W}$ and $\mathrm{HH}$ - emitted and received vertically or horizontally, respectively), or cross-polarized ( $\mathrm{VH}$, and HV - emitted in one orientation and received in another), will have a great effect on the signal backscattered by vegetation (SOUZA et al., 2019). When additional information from backscattering phase is available, the magnitude of the polarimetric response makes possible the characterization of the objects scattering mechanisms as well (GARCIA et al., 20I2).

Many applications of SAR data for forest studies can be found in the literature and, to cite a few: forest biomass estimates (LUCKMAN et al., 1997; SANTOS et al., 2002; BISPO et al., 20I4; BERNINGER et al., 2018; NINGTHOUJAM et al., 20 I8; DEBASTIANI et al., 2019); height or volume estimates (KUMAR et al., 2017; TRIER et al., 2018; GAO et al., 20I8; SANTORO et al., 2018); phenology (KIMBALL et al., 2004; DOSTALOVÁ et al., 20I8; RÜETSCHI et al., 20I8; KOYAMA et al., 2019) and detection of flooded forest (RICHARDS et al., 1987; HESS et al., 1990; TSYGANSKAYA et al., 2018; RESENDE et al., 2019).

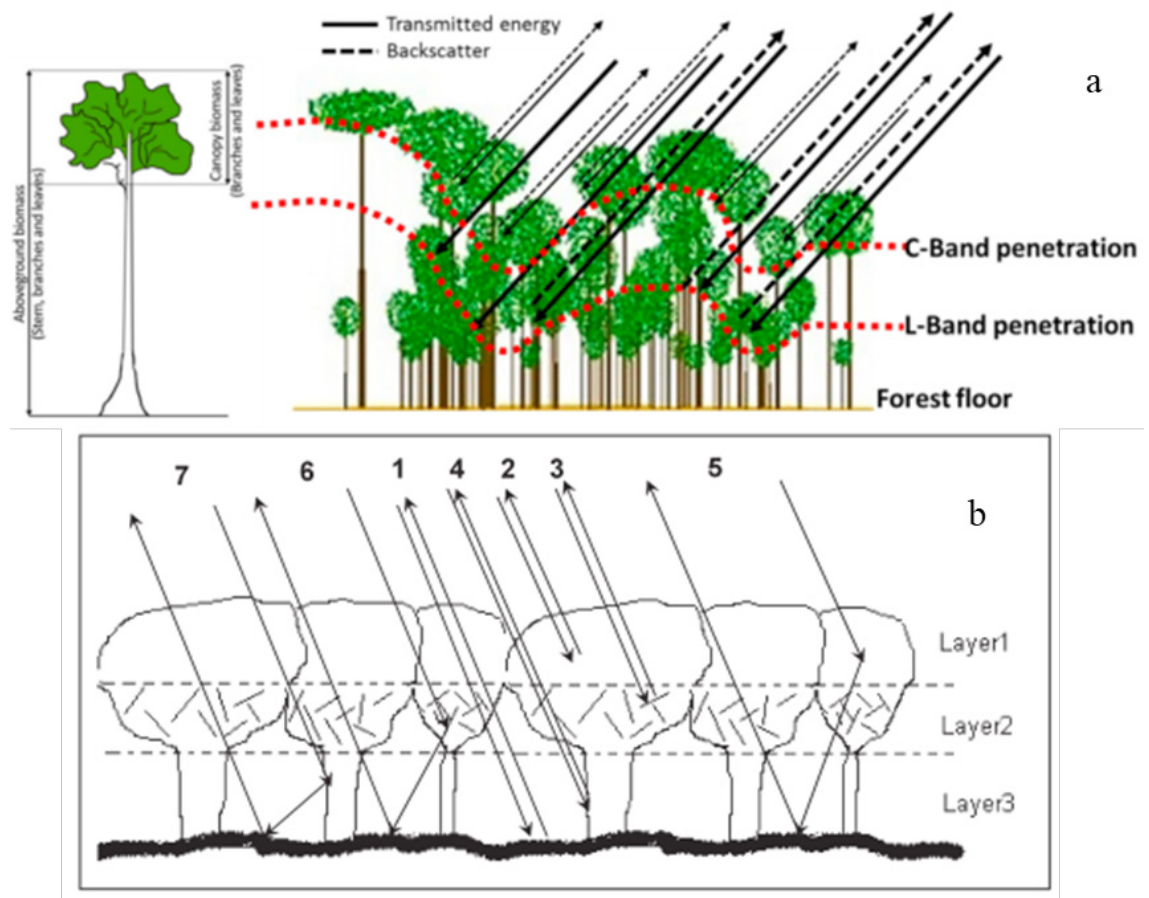

FIGURE I (a) Penetration of the $C$ and $L$ bands wavelenght in the forest canopy. Source: (OMAR et al., 20I7). (b) Geometry of a forest canopy and scattering components: I, soil surface scattering; 2, leaf volume scattering; 3, branch volume scattering; 4, trunk volume scattering; 5, leaf-soil interaction; 6, branch-soil interaction; 7, trunk-soil interaction. Source: (WANG and QI, 2008). 
Since in Brazil there is no review of radar applications in forestry sciences, and due to the existence of several biomes with different vegetation types and associated ecosystems, it is useful to survey the amount and type of researches already made on this theme. Also, the availability of free SAR orbital data (such as Sentinel IA/B, launched by the European Space Agency) encouraged the SAR scientific community to work with these data. The different experiences obtained with SAR studies in Brazilian forests can be used as basis to guide future researches. So, the objective of the present work was to group part of the scientific knowledge generated on the estimate of forest biophysical variables in Brazil based on the application of SAR remote sensing.

\section{RADAR APPLICATIONS AND FOREST BIOPHYSICAL DATA IN BRAZIL}

Brazil has six biomes across its territory, namely: Amazon, Caatinga, Cerrado, Atlantic Forest, Pampa and Pantanal, which present environments with distinct characteristics and vegetation types. In addition, there are to ecosystems associated to mangrove and sandbanks, included in the Atlantic Forest coverage area (MMA, 20I8).

Due to the availability of new SAR systems and images, the number of studies with SAR data for vegetation monitoring and inventory has grown, mainly where the percent of cloud coverage is high and constant as in tropical areas (BISPO et al., 20I2).

Research databases such as Elsevier, ScienceDirect, Springer, Web of Science, Taylor and Francis Online, Google Scholar and MDPI, over time, showed an increasing number of publications with applications of SAR data in forests of Brazil. Most publications started by the end of 1990s and there is an increasing number of studies from this decade and specially a higher number of works published in 2019 (Figure 2a).

Moreover, among these publications, it was observed a significant number of studies in the Amazonian region, followed by application in eucalyptus plantations (Figure 2b). With regard to the SAR sensors most used, it was observed high use of airborne SAR sensors, while at orbital level, ALOS/PALSAR followed by JERS-I were the most applied (Figure 2c).

Luckman et al. (1997) assessed JERS-I, ERS-I and SIR-C $L$ and $C$ bands to estimate biomass density in Amazon forest, observing that $L$ band backscattering saturates around 60 ton/ha. These authors highlighted the limitation of biomass estimates due to the saturation on the biomass/backscatter relationship that occurs at different levels, depending on the SAR wavelength.

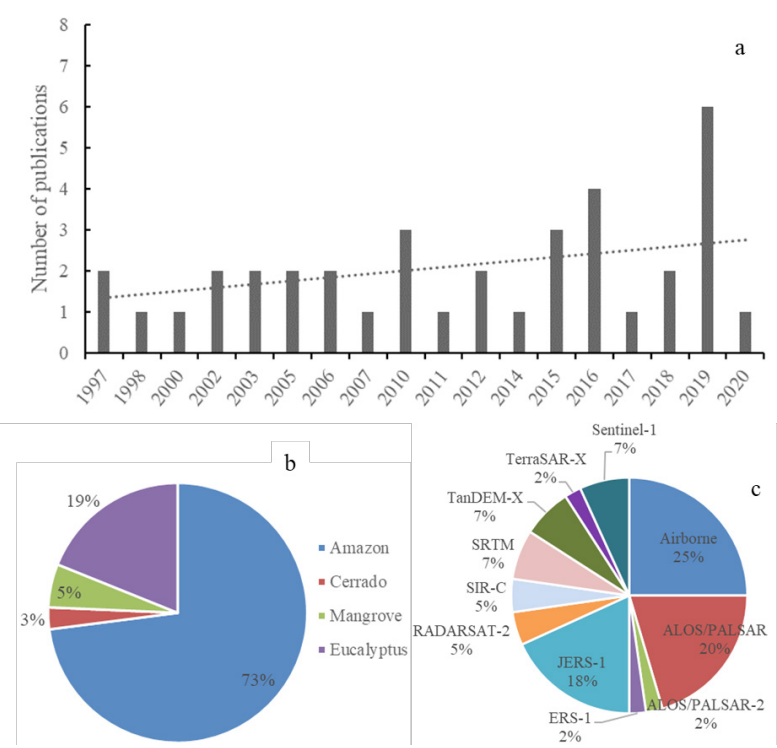

FIGURE 2 Quantitative survey of SAR data scientific production over time (a), quantity by: types of forests studied (b) and radar data source (c).

$\mathrm{L}$ band, presented better performance for biomass estimate when compared to $C$ band and, in general, the longer the wavelength, more precise is the estimate of forest biomass (or higher is the saturation point), and therefore the microwaves longest bands ( $L$ and $P$ ) were the most applied by the researchers in the forests throughout Brazil (Table I).

Backscatter signal saturation was also observed by Bitencourt et al. (2007) when analyzing JERS-I data in different vegetation types of the Cerrado biome (campo cerrado), highlighting the saturation point or detection limit of biomass estimation for $L$ band ranging from 100 to $120 \mathrm{t} / \mathrm{ha}$. Nevertheless, they found a good coefficient of determination to estimate above-ground woody biomass $\left(R^{2}=0.87\right)$. Using these same data, Luckman et al. (1998) based on temporal series and field data in Amazonia, specifically in Tapajós and Manaus, developed a semi-empirical method to obtain biomass density in forests in regeneration/succession, analyzing sources of errors and generating well quantified confidence limits.

Some studies also showed association of SAR and optical data, as in Santos et al. (2002) that used JERSI (Japanese Earth Resources Satellite) SAR data and Landsat Thematic Mapper (TM) optical data to estimate Cerrado and other forest formations biomass in the frontier of Roraima and Mato Grosso states, suggesting that this is a promising method to assess such parameter in this vegetation transition zone. Cutler et al. (20I2) also integrated JERS-I data to Landsat/TM optical data 
TABLE I Studies using SAR data for forest biophysical variables estimates in Brazil.

\begin{tabular}{|c|c|c|c|c|}
\hline Type of forest & Sensor/Platform & Band & SAR variables & Reference \\
\hline Amazon & SIR-C/ SRL-I & L, C & backscattering & Foody et al. (1997) \\
\hline Amazon & SAR/JERS-I, ERS-I, SIR-C & L, C & backscattering & Luckman et al. (1997) \\
\hline Amazon & SAR/JERS-I & $\mathrm{L}$ & backscattering & Luckman et al. (1998) \\
\hline Amazon & JERS-I & $\mathrm{L}$ & backscattering & Kuplich et al. (2000) \\
\hline Amazon & JERS-I & $\mathrm{L}$ & backscattering and texture & Salas et al. (2002) \\
\hline \multicolumn{5}{|l|}{ Amazon (transition zone } \\
\hline between cerrado and & JERS-I & $\mathrm{L}$ & backscattering & Santos et al. (2002) \\
\hline \multicolumn{5}{|l|}{ Amazon forest) } \\
\hline Amazon & AeS-I (AeroSensing Radar Systeme)/Airborne & $\mathrm{P}, \mathrm{X}$ & backscattering and interferometric height & Neeff et al. (2003) \\
\hline Amazon & AeS-I (AeroSensing Radar Systeme)/Airborne & $\mathrm{P}$ & backscattering & Santos et al. (2003) \\
\hline Amazon & JERS-I & $\mathrm{L}$ & texture & Kuplich et al. (2005) \\
\hline Amazon & AeS-I (AeroSensing Radar Systeme)/Airborne & $\mathrm{P}, \mathrm{X}$ & backscattering and interferometric height & Neeff et al. (2005) \\
\hline Amazon & Airborne & $\mathrm{P}$ & backscattering & Santos et al. (2006) \\
\hline Amazon & R99B/Airborne & $\mathrm{L}$ & polarimetric attributes & Narvaes et al. (20I0) \\
\hline Amazon & R99B/Airborne & $\mathrm{L}$ & polarimetric attributes & Gonçalves et al. (20II) \\
\hline Amazon & JERS-I & $\mathrm{L}$ & backscattering and texture & Cutler et al. (2012) \\
\hline Amazon & OrbiSAR-I/Aircraft & $\mathrm{P}, \mathrm{X}$ & polarimetric and interferometric data & Sambatti et al. (20I2) \\
\hline Amazon & ALOS/PALSAR, SRTM & $\mathrm{L}$ & polarimetric attributes & Bispo et al. (20l4) \\
\hline Amazon & TanDEM-X & $\mathrm{X}$ & interferometric coherence & Treuhaft et al. (2015) \\
\hline Amazon & SRTM & $\mathrm{X}$ & geomorphometric variables & Bispo et al. (2016) \\
\hline Amazon & ALOS/PALSAR & $\mathrm{L}$ & polarimetric attributes & Martins et al. (2016) \\
\hline Amazon & TanDEM-X & $\mathrm{X}$ & interferometric phase-height & Treuhaft et al. (2017) \\
\hline Amazon & ALOS/PALSAR, Sentinel-I & $\mathrm{L}, \mathrm{C}$ & backscattering and texture & Bourgoin et al. (2018) \\
\hline Amazon & ALOS/PALSAR, RADARSAT-2, TerraSAR-X & $\mathrm{L}, \mathrm{C}, \mathrm{X}$ & polarimetric attributes & Pereira et al. (20।8) \\
\hline Amazon & TanDEM-X & $\mathrm{X}$ & interferometric data & Bispo et al. (2019) \\
\hline Amazon & ALOS/PALSAR-2 & $\mathrm{L}$ & polarimetric attributes & Cassol et al. (2019) \\
\hline Amazon & Sentinel-I & C & backscattering and texture & Debastiani et al. (2019) \\
\hline Amazon & SRTM & $\mathrm{x}$ & terrain variables & Silveira et al. (2019) \\
\hline Amazon & ALOS/PALSAR & $\mathrm{L}$ & backscattering & $\begin{array}{l}\text { Huggannavar and Shetty } \\
(2020)\end{array}$ \\
\hline Cerrado & JERS-I & $\mathrm{L}$ & backscattering & Bitencourt et al. (2007) \\
\hline Mangrove & RADARSAT-2 & C & backscattering & Cougo et al. (2015) \\
\hline Mangrove & ALOS/PALSAR & $\mathrm{L}$ & backscattering e incoherent attributes & Pereira et al. (2016) \\
\hline $\begin{array}{c}\text { Eucalyptus forest } \\
\text { plantation }\end{array}$ & Airborne, OrbiSAR-I & $\mathrm{P}, \mathrm{X}$ & polarimetric and interferometric data & Gama et al. (2006) \\
\hline Eucalyptus & Airborne & $\mathrm{P}, \mathrm{X}$ & polarimetric and interferometric data & Gama et al. (20I0a) \\
\hline Eucalyptus & Airborne, OrbiSAR-I & $\mathrm{P}, \mathrm{X}$ & polarimetric and interferometric data & Gama et al. (20|0b) \\
\hline Eucalyptus & ALOS/PALSAR & $\mathrm{L}$ & backscattering & Baghdadi et al. (20I5) \\
\hline Eucalyptus & Airborne, OrbiSAR-I & $\mathrm{P}, \mathrm{X}$ & polarimetric and interferometric data & Gama et al. (2016) \\
\hline Eucalyptus & Sentinel-IB, ALOS/PALSAR DEM & C, L & backscattering, terrain atributes and texture & Reis et al. (2019) \\
\hline Eucalyptus & ALOS/PALSAR & $\mathrm{L}$ & backscattering & Souza et al. (2019) \\
\hline
\end{tabular}

to estimate biomass, verifying that the best results were obtained with the radar texture associated with optical bands. Kuplich (2006) also used fused SIR-C SAR and optical data to estimate regenerating (secondary) forest ages in Amazonia, stating that SAR texture measures are essential for this task. Foody et al. (1997) also worked with regenerating forests and found good results for biomass estimates using the backscatter ratio $\mathrm{L}_{\mathrm{HV}} / \mathrm{C}_{\mathrm{HV}}$ with SIR C SAR data.

Gonçalves et al. (20II) investigated the potential use of polarimetry to estimate wood volume in Tapajós National Forest, Brazilian Amazonia, using SAR-R99B airborne system, based on coherent and incoherent polarimetric attributes. The authors concluded that these data can be used to quantify volume and consequently woody biomass of forests, with accuracy similar to that obtained in traditional inventories made in the field. However, they also observed the effect of saturation in the model's estimate.

Salas et al. (2002) indicated environmental conditions (for example: moisture content of soil and vegetation) as influencers in biomass estimate variability while analyzing regenerating forests in Rondônia state, pointing out that this variation does not result from speckle (SAR images inherent noise) or from the texture of the vegetation itself.

Santos et al. (2003) tested polynomial and logarithm functions to estimate biomass at the Tapajós National Forest and concluded that horizontal and crossed polarizations $(\mathrm{HH}$ and $\mathrm{HV}$ ) were adequate 
for that task. Santos et al. (2006), on the other hand, obtained a moderate performance in estimating biomass data from Amazon forest in a different region, with a higher relationship in $\mathrm{HH}$ polarization than that with data obtained with HV.

Narvaes et al. (2010) tested polarimetric attributes of $L$ band collected by R99-B/SIPAM airborne sensor, not only to relate with aboveground biomass of Tapajós National Forest, but to estimate biophysical parameters such as height, diameter, basal area and density. They concluded that "height" variable showed higher association to backscattering values, indicating that the larger the trees, the higher the backscatter, depending on the polarization and incidence angle.

Neeff et al. (2005) modeled interferometric height and backscattering in Amazon tropical forest with airborne $P$ band SAR data. High correlation was found in biomass estimate $\left(r^{2}=0.89\right)$ based on information from backscattering and interferometric height. Sambatti et al. (2012) added interferometric technique to aboveground biomass estimate of Amazonian forest in Paragominas region, based on bands with different levels of canopy penetration ( $P$ and $X)$ of airborne SAR. The authors assessed backscattering and interferometric variables of each forest class and observed a good estimate $\left(r^{2}=0.82\right)$ using interferometric height and $P$ band $\mathrm{HV}$ and $\mathrm{W}$ polarizations.

Treuhaft et al. (2017) used TanDEM-X radar interferometry and obtained a proportional relation of aboveground biomass rate and phase height, suggesting that combination of $X$ and $L$ bands could be used as well as LiDAR data to assess biomass dynamics and vegetation structure of Tapajós National Forest. Treuhaft et al. (2015) also used TanDEM-X's $X$ band interferometry to estimate forest biomass in Tapajós National Forest and observed distortion between $29 \%$ and $35 \%$ of average biomass, indicating that the use of multiple polarizations and alternative estimate models can provide better results. Bispo et al. (2019) also applied the interferometric technique (InSAR) using TanDEM-X with the aid of LiDAR data to map successional stages of the forest from the estimation of its height, achieving an accuracy of about $80 \%$.

Kuplich et al. (2000) analyzed the relation of JERSI images' backscattering with biomass of regenerating forests with different origins (block-logged and selectively logged). They concluded that young regenerating forests following block-logging (clear-cut) are more prone to be detected by $L$ band SAR data. Kuplich et al. (2005) related SAR images' texture to biomass of regenerating tropical forest in the Brazilian Amazonia, next to Manaus and Santarém cities, and simulated images with seven texture measures. Contrast texture measure, derivated from the Gray-Level Co-Occurrence Matrix (GLCM), using JERS-I L band, was the one that contributed most to the accuracy increase in forest biomass estimates.

Pereira et al. (2018) also observed the higher accuracy of ALOS/PALSAR's L band in Amazonia forest biomass estimate when compared to RADARSAT- 2 and TerraSAR-X $C$ and $X$ bands, respectively. The authors identified ALOS/PALSAR's $L$ band high potential to support estimates of structural attributes of floodplain forest. They obtained the higher accurate estimates from the proportion of volumetric scattering, and the difference of the first and second dominant phase between trihedral and dihedral scattering extracted, respectively, from polarimetric decomposition from Van Zyl and Touzi matrices.

Cougo et al. (2015) assessed RADARSAT-2 backscattering to model structural characteristics of regenerating mangrove Brazil's North coast, and observed that $\mathrm{HH}$ and $\mathrm{W}$ co-polarization produced highly accurate estimates with $r^{2}$ of $0.8 \mathrm{I}$ for average height, $r^{2}=0.79$ for DBH (diameter at breast height), $r^{2}=0.67$ for basal area and $r^{2}=0.79$ for above ground biomass (Figure 3). Pereira et al. (2016), on the other hand, observed stronger results in estimate of canopy height, average height and average $\mathrm{DBH}$ of mangrove using linear multiple regression based on incoherent attributes obtained by BMI (Biomass Index) and CSI (Canopy Structure Index) indices as explanatory variables for ALOS/PALSAR.

Cassol et al. (2019) while using ALOS/PALSAR-2 data in regenerating Amazonian forest observed strong relation between polarimetric attributes and structural parameters using multiple linear regression, also noticing that the forest biophysical variables presented positive correlation with volumetric scattering, and that the combination of multiple prediction variables with multiple linear regression models improved by $70 \%$ the estimate of aboveground biomass.

Huggannavar and Shetty (2020) applied various polarization combinations $(\mathrm{HH}+\mathrm{HV}, \mathrm{HH}-\mathrm{HV}, \mathrm{HH}+$ $\mathrm{HV} / \mathrm{HH}-\mathrm{HV}$ ) of the ALOS / PALSAR L band and the NDVI vegetation index from Landsat 7 images to estimate above-ground biomass in an area of Paragominas, state of Pará. The authors observed that the individual data of each sensor ( $\mathrm{HV}$ presented better sensitivity with an $R^{2}=0.559$, and the NDVI $R^{2}=0.298 I$ ) offered a lower relation with the variable analyzed, since the empirical model obtained from multiple linear regression using the 

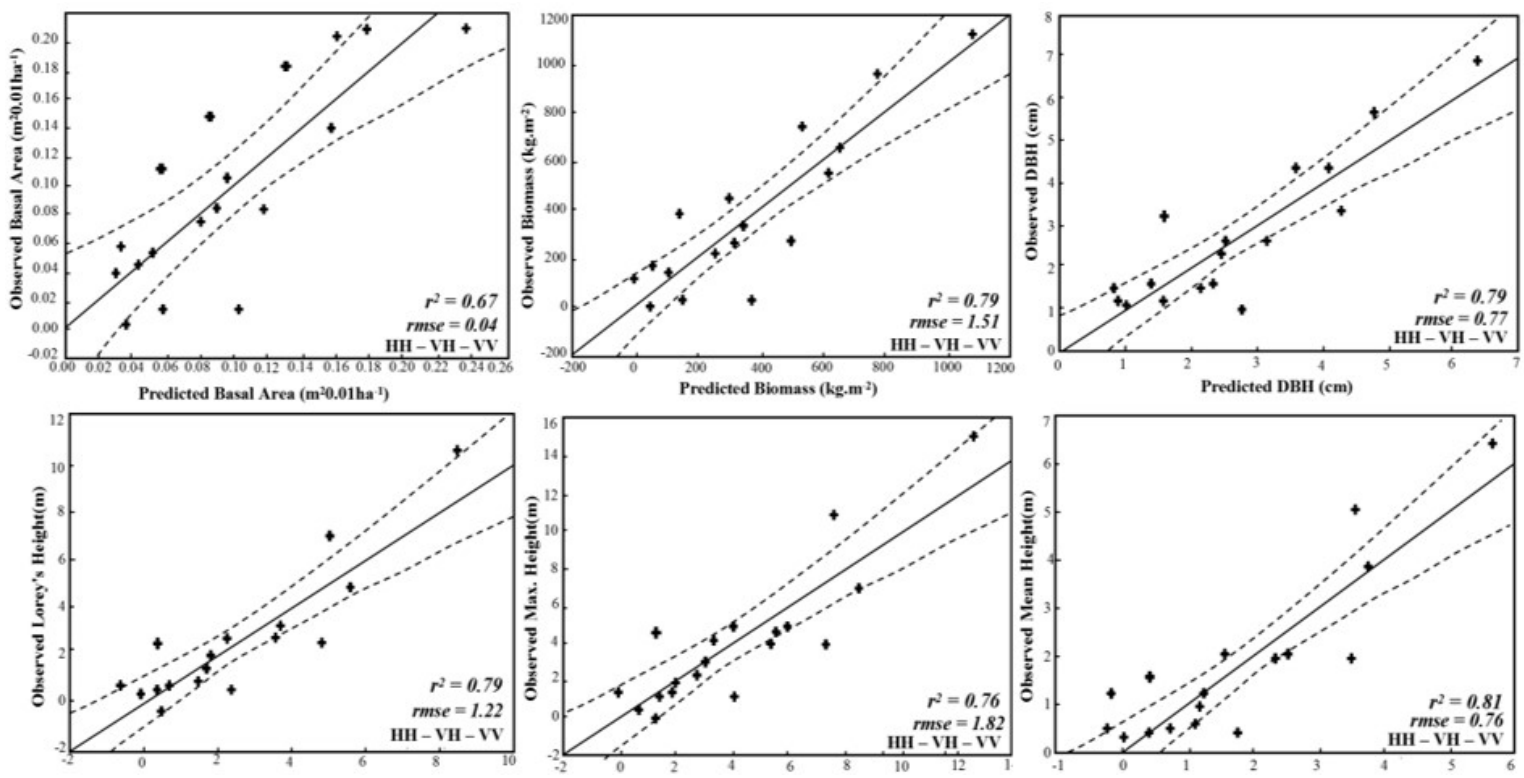

FIGURE 3 Relationship between observed and estimated values for the variables: Basal area, biomass, DBH (diameter at breast height), and Lorey heights, maximum and average. Source: Cougo et al. (2015).

combination NDVI and $\mathrm{HH}+\mathrm{HV}$ produced an $\mathrm{R}^{2}$ of 0.73 during calibration and 0.363 during validation. Among the polarization combinations, $\mathrm{HH}+\mathrm{HV}$ presented the best performance $\left(R^{2}=0.6574\right)$.

Martins et al. (2016) while assessing polarimetric attributes (coherent and incoherent) of ALOS/PALSAR, also using $L$ band, at the North of Amazonia, concluded that anisotropy, double-bounce component, orientation angle, volume index, phase difference and backscattering coefficient were important to explain biomass through multiple regression analysis.

Bispo et al. (20/4) used three models to biomass estimate in the Amazon forest. The first one involved exclusively polarimetric parameters data extracted from ALOS/PALSAR, the second one combined these same data with a cosine factor, and the third one integrated these data to geomorphometric variables obtained from SRTM (Shuttle Radar Topography Mission), and it was verified that this was the best model to estimate forest biomass. Still using SRTM data, Bispo et al. (2016) verified the hypothesis of geomorphometric characteristics being good predictors for primary forest structure in Amazonia. They associated SRTM data to basal area, height and average percent of canopy, and could observe better results for basal area modeling, with coefficient of determination of 0.52 .

Silveira et al. (2019) also associated terrain data obtained from SRTM, using I 4 variables to estimate aboveground biomass, also integrating environmental information and vegetation indexes (from Landsat-5 TM) and observed that the best model $\left(R^{2}=0.57\right.$, and $\left.R M S E=33.43 \mathrm{Mg} / \mathrm{ha}\right)$ was obtained by combining the 3 data types.

Debastiani et al. (2019) were one of the pioneers to use Sentinel-I imagery to estimate above-ground biomass in the Amazon region, specifically in the Jamari National Forest, State of Rondônia, using not only SAR backscatter at $\mathrm{W}$ and $\mathrm{VH}$ polarizations as well as texture metrics and the combination with vegetation indexes from Sentinel-2 optical data. The authors concluded that the use of Sentinel-I C-band allowed to accurately quantify (RMSE $=23.9 \%)$ forest biophysical parameters, however, the integration of optical and texture data enabled an improvement in modeling when compared only with the SAR data, and the Random Tree algorithm was the model with best performance among the others evaluated.

Bourgoin et al. (2018) also used Sentinel-I SAR data in conjunction with ALOS/PALSAR and Landsat and MODIS optical images to model above-ground biomass in degraded forest in the municipality of Paragominas, State of Pará. They concluded that radar data did not were sensitive enough to model the analyzed variable, indicating a time series approach which would provide more information about forest canopy characteristics. The authors also highlight the importance of image preprocessing steps, such as noise reduction through speckle filtering. Nevertheless, the generated model had an RMSE of $97.1 \mathrm{Mg}$ ha $^{-1}$, explaining $28 \%$ of variance, and verifying that $87 \%$ of the mapped forest is degraded.

Baghdadi et al. (2015) used ALOS/PALSAR images in eucalyptus plantations in São Paulo state and 
observed that the use of plantation age along with SAR data slightly improved the results of forest biomass estimate, suggesting, therefore, the use of temporal series to predict this variable. Souza et al. (20/9) tested support vector approach to estimate wood volume in a commercial Eucalyptus grandis plantation in eastern Minas Gerais State, and found that the Radis Basis Function was the most suitable kernel function for model development. The Support Vector Regression (SVR) model allowed the wood volume of eucalyptus plantations to be accurately predicted. In addition, they found that combining the AVNIR-2 (Advanced Visible and Near Infrared Radiometer) optical data with the $L$ band in the polarization $\mathrm{HV}$ from ALOS/PALSAR produced the most accurate SVR model $\left(R^{2}=0.926\right)$.

Still in the state of Minas Gerais, in the municipality of Diamantina, Reis et al. (2019) estimated the volume of eucalyptus cones (in plantations with $E$. urophylla and $E$. grandis) at different ages from Sentinel-IB data ( $W$ and $\mathrm{VH}, \mathrm{VH} / \mathrm{V}$ and $\mathrm{W} / \mathrm{VH}$ ratio, and the ratio $(\mathrm{VH}-\mathrm{V}) / 2$ ). They also used terrain attributes extracted from Digital Elevation Model DEM from ALOS/PALSAR with a spatial resolution of $12.5 \mathrm{~m}$ and Landsat-8 OLI multispectral imagery. Using the Random Forest machine learning algorithm it was found that the individual use of each data type did not provide accurate volume estimates, while integrating all data with the planting age improved the estimate (over $71 \%$ ).

Gama et al. (2006) used interferometry and polarimetry with airborne $\mathrm{X}$ and $\mathrm{P}$ bands for estimate of biophysical parameters of populations of Eucalyptus grandis aiming at cellulose production in Pindamonhangaba, São Paulo State. The authors observed good prediction of tree diameter, commercial height and volume data, with determination indices ranging from 84 to $88 \%$ against forest inventory in field, indicating, therefore, the high potential of SAR interferometry to be used as support in inventories of large areas.

Gama et al. (2010a) using SAR interferometry in $X$ and $P$ bands, with different polarizations to generate elevation models (EM) and assess altimetric quality estimate in populations of Eucalyptus, observed that, in forest area, $\mathrm{P}$ band and particularly $\mathrm{HH}$ polarization suffer lower disturbance for interacting with the vegetation horizontal components instead of vertical components.

Gama et al. (2010b) by integrating polarimetry and interferometry modeled volume and biomass of Eucalyptus planted forests, observed a prediction error of around $10 \%$ for both variables using the models with combination of interferometric height and Canopy
Scattering Index (CSI) which is obtained by the relation of backscatter coefficient $\left(\sigma^{\circ}\right) \mathrm{W}$ by the sum of $\sigma_{\mathrm{W}}^{\circ}$ and $\sigma^{\circ}{ }_{H H}$, using $X$ and $P$ band SAR and OrbiSAR-I (airborne radar) sensor images. Gama et al. (2016) verified Eucalyptus sp. biophysical parameters using $\mathrm{P}$ and $\mathrm{X}$ bands, and concluded that it would be possible to use only $X$ band interferometric survey, based on logHint variable, for the model of vegetation volume in annual volume estimates.

The use of SAR data can be useful in reducing costs to obtain biophysical information on forests. Gama et al. (2016) also mention reduction in costs of forest inventories using SAR interferometric surveys. The cost associated to obtention of data on forests structure was also mentioned by Neeff et al. (2003) while analyzing the modeling of diameters of populations of different types of forest in Amazonia, indicating that it is possible to collect precise information on forest management and assessment of ecosystem at low cost.

Moreover, SAR image is relevant for the modeling of aboveground biomass with errors inferior to $20 \%$, demonstrating the potential of use of SAR data and techniques to estimate biomass of natural and planted forests when compared to field inventory only, optimizing the survey of information in large areas with acceptable precision (SANTOS et al., 20I4).

\section{CONCLUSIONS}

SAR data is now an important information source for forest studies in Brazil. Most of the studies reported here were done in Amazonia biome, probably due to the great utility of SAR data in a nearly constantly cloud-covered. Further studies are needed to verify the potential of SAR data for studies in the remaining biomes in Brazil.

$L$ and $P$ band SAR data, when available, are the most adequate for forest studies, when estimating biomass and forest biophysical variables and when simply mapping deforestation. SAR image texture is a strong ally to forest studies as it captures the spatial domain of the canopy, which is related to age and conservation status of the forest.

It is also important to highlight the limitations of using these type of data for the estimate of aboveground biomass, which may suffer saturation on the backscatter/ biomass relationship and prevent estimates above certain levels, depending on the wavelength/band used. Also, limitations on the use of SAR data for forest studies can include few SAR systems proving free data (with less SAR parameters globally available), low temporal repeativity, small possibilities of time composite with optical data, limited area coverage, non-availability of 
global-level coherent datasets of SAR, along with the general uncertainties that are involved in remote sensing (SINHA et al., 20I5).

There is still a long way to go when using state of the art SAR polarimetry and interferometry techniques for forest studies, but the tendency is to see increasing number of works using these techniques, mainly because free SAR data such as Sentinel-I are available. Also, SAR image processing systems are increasingly accessible. The integration of SAR and optical images is always useful for vegetation studies and also may appear in an increasing number of publications with the availability of high quality free orbital data.

\section{AKNOWLEDGEMENTS}

The authors thank the financial support provided

by the Higher Education Personnel Improvement Coordination (CAPES) for this research.

\section{REFERENCES}

BAGHDADI, N.; MAIRE, G.; BAILLY, J.-S.; NOUVELLON, Y.; OSE, K.; ZRIBI, M.; LEMOS, C.; HAKAMADA, R. Evaluation of ALOS/PALSAR L-band data for the estimation of Eucalyptus plantations aboveground biomass in Brazil. IEEE Journal of Selected Topics in Applied Earth Observations and Remote Sensing, v. 8, n. 8, p. 3802-38II, 2015.

BERNINGER, A.; LOHBERGER, S.; STANGEL, M.; SIEGERT, F. SAR-Based estimation of above-ground biomass and its changes in Tropical Forests of Kalimantan using L-and C-band. Remote Sensing, v. 10, n. 6, 831, 2018.

BISPO P. C.; SANTOS, J. R.; VALERIANO, M. M.; GRAÇA, P. M. L. A. Efeito da topografia na resposta polarimétrica de floresta tropical em imagens PALSAR/ALOS. Ambiência, v. 8 , n. 4, p. $501-510,2012$.

BISPO, P. C.; SANTOS, J. R.; VALERIANO, M. M.; TOUZI, R.; SEIFERT, F. M. Integration of polarimetric PALSAR attributes and local geomorphometric variables derived from SRTM for forest biomass modeling in Central Amazonia. Canadian Journal of Remote Sensing, v. 40, n. I, p. 26-42, 2014.

BISPO, P. C.; SANTOS, J. R.; VALERIANO, M. M.; GRAÇA, P. M. L. A.; BALZTER, H.; FRANÇA, H.; BISPO, P. C. Predictive models of primary tropical forest structure from geomorphometric variables based on SRTM in the Tapajós Region, Brazilian Amazon. Plos One, v. I I, n. 6, p. e0I52009, 2016.

BISPO, P. C.; PARDINI, M.; PAPATHANASSIOUC, K. P.; KUGLER, F;; BALZTER, H.; RAINS, D.; SANTOS, J. R.; RIZAEV, I. G.; TANSEY, K.; SANTOS, M. N.; ARAUJO, L. S. Mapping forest successional stages in the Brazilian Amazon using forest heights derived from TanDEM-X SAR interferometry. Remote Sensing of Environment, v. 232, p. IIII94, 2019.
BITENCOURT, M. D.; MESQUITA JUNIOR, H. N.; KUNTSCHIK, G.; ROCHA, H. R.; FURLEY, P. A. Cerrado vegetation study using optical and radar remote sensing: two Brazilian case studies. Canadian Journal of Remote Sensing, v. 33, n; 6, p. 468-480, 2007.

BOURGOIN, C.; BLANC, L.; BAILLY, J.-S.; CORNU, G.; BERENGER, E.; OSZWALD, J.; TRITSCH, I.; LAURENT, F; HASAN, A. F; SIST, P.; GOND, V. The Potential of Multisource Remote Sensing for Mapping the Biomass of a Degraded Amazonian Forest. Forests, v. 9, n. 6, 303, 2018.

CASSOL, H. L. G.; CARREIRAS, J. M. B.; MORAES, E. C.; ARAGÃO, L. E. O. C.; SILVA, C. V. J.; QUEGAN, S.; SHIMABUKURO, Y. Retrieving Secondary Forest Aboveground Biomass from Polarimetric ALOS-2 PALSAR-2 Data in the Brazilian Amazon. Remote Sensing, v.II, n. I, p. I-32, 2019.

COUGO, M.; SOUZA-FILHO, P. W. M.; SILVA, A. Q.; FERNANDES, M. E. B.; SANTOS, J. R.; ABREU, $M$. R. S.; NASCIMENTO, W. R.; SIMARD, M. Radarsat-2 backscattering for the modeling of biophysical parameters of regenerating mangrove forests. Remote Sensing, v. 7, n. I2, p. I7097-I7| I2, 2015.

CUTLER, M. E. J.; BOYD, D. S.; FOODY, G. M.; VETRIVEL, A. Estimating tropical forest biomass with a combination of SAR image textureand Landsat TMdata: An assessment of predictions between regions. ISPRS Journal of Photogrammetry and Remote Sensing, v.70, p. 66-77, 2012.

DEBASTIANI, A.; SANQUETTA, C.; CORTE, A.; PINTO, N.; REX, F. Evaluating SAR-optical sensor fusion for aboveground biomass estimation in a Brazilian tropical forest. Annal of Forest Research, v. 62, n. I, p. 109-122, 2019.

DOSTALOVÁ, A.; WAGNER, W.; MILENKOVIĆ, M.; HOLLAUS, $M$. Annual seasonality in Sentinel-I signal for forest mapping and forest type classification. International Journal of Remote Sensing, v. 39, n. 21 , p. 7738-7760, 2018.

FOODY, G. M.; GREEN, R. M.; LUCAS, R. M.; CURRAN, P. J.; HONZAK, M.; AMARAL, I. Observations on the relationship between SIR-C radar backscatter and the biomass of regenerating tropical forests. International Journal of Remote Sensing, v. 18, n. 3, p. 687-694, 1997.

GAMA, F. F; SANTOS, J. R.; MURA, J. C.; RENNÓ, C. D. Estimativa de parâmetros biofísicos de povoamentos de Eucalyptus através de dados SAR. Ambiência, v. 2, n. 3, p. 29-42, 2006.

GAMA, F. F; MURA, J. C.; SANTOS, J. R.; ALBUQUERQUE, P. C. G. Avaliação do potencial da interferometria SAR para o mapeamento altimétrico de áreas reflorestadas por Eucalyptus sp. Boletim de Ciências Geodésicas, v. I6, n. 4, p. 519-537, 2010a.

GAMA, F. F.; SANTOS, J. R.; MURA, J. C. Eucalyptus biomass and volume estimation using interferometric and polarimetric SAR data. Remote Sensing, v. 2, n. 4, p. 939-956, $2010 \mathrm{~b}$. 
GAMA, F. F; SANTOS, J. R.; MURA, J. C. Continuous monitoring of biophysical Eucalyptus sp. parameters using interferometric synthetic aperture radar data in $P$ and $X$ bands. Journal of Applied Remote Sensing, v. 10, n. 2, p. 026002,2016 .

GAO, T.; ZHU, J. J.; YAN, Q. L.; DENG, S. Q.; ZHENG, X.; ZHANG, J. X.; SHANG, G. D. Mapping growing stock volume and biomass carbon storage of larch plantations in Northeast China with L-band ALOS PALSAR backscatter mosaics. International Journal of Remote Sensing, v. 39 , n. 22, p. 7978-7997, 2018.

GARCIA, C. E.; SANTOS, J. R.; MURA, J. C.; KUX, H. J. $H$. Análise do potencial de imagem TerraSAR-X para mapeamento temático no sudoeste da Amazônia brasileira. Acta Amazonica, v. 42, n. 2, p. 205-2।4, 2012.

GONÇALVES, F. G.; SANTOS, J. R.; TREUHAFT, R. N. Stem volume of tropical forests from polarimetric radar. International Journal of Remote Sensing, v. 32, n. 2, p. 503-522, 2011 .

HESS, L. L.; MELACK, J. M.; SIMONETT, D. S. Radar detection of flooding beneath the forest canopy: a review. International Journal of Remote Sensing, v. I I, n. 7, p. |3|3-|325, 1990.

HUGGANNAVAR, V.; SHETTY, A. Biomass Estimation Using Synergy of ALOS-PALSAR and Landsat Data in Tropical Forests of Brazil. In: GHOSH, J.; SILVA, I. Applications of Geomatics in Civil Engineering. Switzerland: Springer, 2020. p. 593-603.

JOSHI, N. P.; MITCHARD, E. T. A.; SCHUMACHER, J.; JOHANNSEN, V. K.; SAATCHI, S.; FRENSHOLT, R. L-Band SAR Backscatter related to forest cover, height and aboveground biomass at multiple spatial scales across Denmark. Remote Sensing, v. 7, n. 4, p. 4442-4472, 2015.

KAASALAINEN, S.; HOLOPAINEN, M.; KARJALAINEN, M.; VASTARANTA, M.; KANKARE, V.; KARILA, K.; OSMANOGLU, B. Combining Lidar and Synthetic Aperture Radar data to estimate forest biomass: status and prospects. Forests, v. 6, n. I, p. 252-270, 2015.

KIMBALL, J. S.; MCDONALD, K. C.; RUNNING, S. W.; FROLKING, S. E. Satellite radar remote sensing of seasonal growing seasons for boreal and subalpine evergreen forests. Remote Sensing of Environment, v. 90, n. 2, p. 243-258, 2004.

KOYAMA, C. N.; WATANABE, M.; HAYASHI, M.; OGAWA, T.; SHIMADA, M. Mapping the spatial-temporal variability of tropical forests by ALOS-2 L-band SAR big data analysis. Remote Sensing Environment, v. 233, I I I372, 2019.

KUMAR, S.; KHATI, U. G.; CHANDOLA, S.; AGRAWAL, S.; KUSHWAHA, S. P. S. Polarimetric SAR interferometry based modeling for tree height and aboveground biomass retrieval in a tropical deciduous forest. Advances in Space Research, v. 60, n. 3, p. 57I-586, 2017.
KUPLICH, T. M. Estudos florestais com imagens de radar. Espaço \& Geografia, v. 6, n. I, p. 65-90, 2003.

KUPLICH, T. M.; CURRAN, P. J.; ATKINSON, P. M. Relating SAR image texture to the biomass of regenerating tropical forests. International Journal of Remote Sensing, v. 26, n. 2I, p. 4829-4854, 2005.

KUPLICH, T. M, SALVATORI, V.; CURRAN, P. J. JERS-I/ SAR backscatter and its relationship with biomass of regenerating forests. International Journal of Remote Sensing, v. 21, n. 12, p. 2513-2518, 2000.

LUCKMAN, A.; BAKER, J.; KUPLICH, T. M.; YANASSE, C. C. F; FRERY, A. C. A study of the backscatter and biomass for relationship regenerating spaceborne SAR between radar tropical forest instruments. Remote Sensing of Environment, v. 60, n. I, p. I-13, 1997.

LUCKMAN, A.; BAKER, J.; HONZÁK, M.; LUCAS, R. Tropical forest biomass density estimation using JERS-I SAR: seasonal variation, confidence limits, and application to image mosaics. Remote Sensing of Environment, v. 63, n. 2, p. 126-139, 1998.

MARTINS, F. S. R. V.; SANTOS, J. R.; GALVÃO, L. S.; XAUD, H. A. M. Sensitivity of ALOS/PALSAR imagery to forest degradation by fire in northern Amazon. International Journal of Applied Earth Observation and Geoinformation, v. 49, p. 163-174, 2016.

MMA. Ministério do Meio Ambiente. Biomas. 2018. Available at: http://www.mma.gov.br/biomas.html. Accessed in:_30 setembro 2018.

NARVAES, I. S.; SANTOS, J. R.; SILVA, A. Q. Analysis of structural parameters of forest typologies using L-band SAR data. Boletim de Ciências Geodésicas, v. 16, n. 3, p. 475-489, 2010.

NEEFF, T.; DUTRA, L. V.; SANTOS, J. R.; FREITAS, C. C.; ARAUJO, L. S. Tropical forest stand table modelling from SAR data. Forest Ecology and Management, v. I86, p. I59-I 70, 2003.

NEEFF, T.; DUTRA, L. V.; SANTOS, J. R.; FREITAS, C. C.; ARAUJO, L. S. Tropical forest measurement by interferometric height modeling and P-Band radar backscatter. Forest Science, v. 5I, n. 6, p. 585-594, 2005.

NINGTHOUJAM, R. K.; JOSHI, P. K.; ROY, P. S. Retrieval of forest biomass for tropical deciduous mixed forest using ALOS PALSAR mosaic imagery and field plot data. International Journal of Applied Earth Observation and Geoinformation, v. 69, p. 206-216, 2018.

OMAR, H.; MISMAN, M. A.; KASSIM, A. R. Synergetic of PALSAR-2 and Sentinel-IA SAR polarimetry for retrieving aboveground biomass in dipterocarp forest of Malaysia. Applied Sciences, v.7, n. 7, p. 675, 2017. 
PEREIRA, F. R. S.; KAMPEL, M.; CUNHA-LIGNON, M. Mangrove vegetation structure in Southeast Brazil from phased array L-band synthetic aperture radar data. Journal of Applied Remote Sensing, v. I0, n. 3, p. 03602 I, 2016.

PEREIRA, L. O.; FURTADO, L. F. A.; NOVO, E. M. L. M.; SANT'ANNA, S. J. S.; LIESENBERG, V.; SILVA, T. S. F. Multifrequency and full-polarimetric SAR assessment for estimating above ground biomass and Leaf Area Index in the Amazon Várzea Wetlands. Remote Sensing, v. 10, n. 9 , p. $1355,2018$.

REIS, A. A.; FRANKLIN, S. E.; MELLO, J. M.; ACERBI JUNIOR, F. W. Volume estimation in a Eucalyptus plantation using multi-source remote sensing and digital terrain data: a case study in Minas Gerais State, Brazil. International Journal of Remote Sensing, v. 40, n. 7, p. 2683-2702, 2019.

RESENDE, A. F.; SCHÖNGART, J.; STREHER, A. S.; FERREIRAFERREIRA, J.; PIEDADE, M. T. F.; SILVA, T. S. F. Massive tree mortality from flood pulse disturbances in Amazonian floodplain forests: The collateral effects of hydropower production. Science of The Total Environment, v. 659, p. 587-598, 2019.

RICHARDS, J. A.; WOODGATE, P. W.; SKIDMORE, A. K. An explanation of enhanced radar backscattering from flooded forests. International Journal of Remote Sensing, v. 8, n. 7, p. 1093-I 100, 1987.

RÜETSCHI, M.; SCHAEPMAN, M. E.; SMALL, D. Using multitemporal Sentinel-I C-band backscatter to monitor phenology and classify deciduous and coniferous forests in northern Switzerland. Remote Sensing, v. I0, n. I, p. 55, 2018

SALAS, W. A.; DUCEY, M. J.; RIGNOT, E.; SKOLE, D. Assessment of JERS-I SAR for monitoring secondary vegetation in Amazonia: II. Spatial, temporal, and radiometric considerations for operational monitoring. International Journal of Remote Sensing, v. 23, n. 7, p. |38|-| 399, 2002.

SAMBATTI, J. B. M.; LEDUC, R.; LUBECK, D.; MOREIRA, J. R.; SANTOS, J. R. Assessing forest biomass and exploration in the Brazilian Amazon with airborne InSAR: an alternative for REDD. The Open Remote Sensing Journal, v. 5, p. $21-36,2012$.

SANTORO, M.;WEGMÜLLER, U.; ASKNE, J. Forest stem volume estimation using C-band interferometric SAR coherence data of the ERS-I mission 3-days repeat-interval phase. Remote Sensing of Environment, v. 216, p. 684-696, 2018.

SANTOS, J. R.; LACRUZ, M. S. P.; ARAUJO, L. S.; KEIL, M. Savanna and tropical rainforest biomass estimation and spatialization using JERS-I data. International Journal of Remote Sensing, v. 23, n. 7, p. I217-1229, 2002.

SANTOS, J. R.; FREITAS, C. C.; ARAUJO, L. C.; DUTRA, L. V.; MURA, J. C.; GAMA, F. F.; SOLER, L. S.; SANT'ANNAS. J. S. Airborne P-band SAR applied to the aboveground biomass studies in the Brazilian tropical rainforest. Remote Sensing of Environment, v. 87, n. 4, p. 482493, 2003
SANTOS, J. R.; ARAUJO, L. S.; KUPLICH, T. M.; FREITAS, C. C.; DUTRA, L. V.; SANT'ANNA, S. J. S.; GAMA, F. F. Tropical forest biomass and its relationship with P-band SAR data. Revista Brasileira de Cartografia, v. 58, n. I, p. 37-42, 2006.

SANTOS, J. R.; GAMA, F. F.; BISPO, P. C. Estimating forest biomass by remote sensing radar data in Brazil. Drewno, $v$. 57, n. 192, p. II9-132, 2014.

SANTOS, J. R.; GONÇALVES, F. G. Polarimetric responses patterns and scattering mechanisms of forest targets from L-band radar. Revista Brasileira de Cartografia, v. 6 I, n. 4, p. 39l-397, 2009.

SILVEIRA, E. M. O.; CUNHA, L. I. F.; GALVÃO, L. S.; WITHEY, K. D.; ACERBI JÚNIOR, F. W.; SCOLFORO, J. R. S. Modelling aboveground biomass in forest remnants of the Brazilian Atlantic Forest using remote sensing, environmental and terrain-related data. Geocarto International, 36 p., 2019.

SINHA, S.; JEGANATHAN, C.; SHARMA, L. K.; NATHAWAT, M. S. A review of radar remote sensing for biomass estimation. International Journal of Environmental Science and Technology, v. I2, p. I779-I 792, 2015.

SOUZA, G. S. A.; SOARES, V. P.; LEITE, H. G.; GLERIANI, J. M.; AMARAL, C. H.; FERRAZ, A. S.; SILVEIRA, M. V. F.; SANTOS, J. F. C.; VELLOSO, S. G. S.; DOMINGUES, G. F.; SILVA, S. Multi-sensor prediction of Eucalyptus stand volume: A support vector approach. ISPRS Journal of Photogrammetry and Remote Sensing, v. I56, p. I35-|46, 2019.

TREUHAFT, R.; GONÇALVES, F. G.; SANTOS, J. R.; KELLER, M. M.; PALACE, M.; MADSEN, S.; SULLIVAN, F; GRAÇA, P. M. L. A. Tropical-forest biomass estimation at $X$-Band from the spaceborne TanDEM-X interferometer. IEEE Geoscience and Remote Sensing Letters, v. 12, n. 2, p. 239-243, 2015.

TREUHAFT, R.; LEI, Y.; GONÇALVES, F; KELLER, M.; SANTOS, J. R.; NEUMANN, M.; ALMEIDA, A. TropicalForest structure and biomass dynamics from TanDEM-X radar interferometry. Forests, v. 8, n. 8, p. 277, 2017.

TRIER, Ø. D.; SALBERG, A.-B.; HAARPAINTNER, J.; AARSTEN, D.; GOBAKKEN, T.; NAESSET, E. Multi-sensor forest vegetation height mapping methods for Tanzania. European Journal of Remote Sensing, v. 5I, n. I, p. 587-606, 2018

TSYGANSKAYA, V.; MARTINIS, S.; MARZAHN, P.; LUDWIG, R. SAR-based detection of flooded vegetation - a review of characteristics and approaches. International Journal of Remote Sensing, v. 39, n. 8, p. 2255-2293, 2018.

WANG, C.; Qi, J. Biophysical estimation in tropical forests using JERS-I SAR and VNIR imagery. II. Aboveground woody biomass. International Journal of Remote Sensing, v. 29 , n. 23, p. 6827-6849, 2008. 